\title{
LAG3 Gene
}

National Cancer Institute

\section{Source}

National Cancer Institute. LAG3 Gene. NCI Thesaurus. Code C104620.

This gene is involved in the activation of T-cells and natural killer cells. 